\title{
Poor College Students' Resilience Phase in Online Learning during the Covid-19 Pandemic
}

(Fase Resiliensi Mahasiswa Miskin dalam Pembelajaran Daring di Masa Pandemi Covid-19)

\author{
Andi Wahyu Irawan*, Rury Muslifar, Dwisona Dwisona \\ Department of Guidance and Counseling, Faculty of Teacher Training and Education, Universitas Mulawarman, \\ Kuaro St., Samarinda, East Kalimantan, 75119 Indonesia \\ *corresponding author, e-mail: andiwahyuirawan@fkip.unmul.ac.id
}

Article received: April $5^{\text {th }} 2021$; revised: May $12^{\text {th }} 2021$; accepted: May $30^{\text {th }} 2021$

\begin{abstract}
After a year of the Covid-19 pandemic, online learning remains to be carried out in Indonesia. In this situation, college students have to survive with excellent resilience amid various restraints. This study investigates the poor college students' resilience phase in online learning during the Covid-19 pandemic. With the qualitative inquiry narrative method, this study involved 30 college students from Universitas Mulawarman as the participants. The participants were selected through the purposive sampling technique and interviewed via phone call. The analysis process was carried out using the induction and deduction process, while the analysis was completed based on the field data and referred to the theory in the deduction process. The research results show that college students experience three resilience phases in online learning: survival, adaptation, and recovery. The survival stage occurs in the initial months of online learning, while the adaptation phase occurs in the first six months of online learning. From the tenths month of online learning, students have reached the recovery stage. Following this research finding, guidance and counseling services in the universities are required to facilitate poor students to enhance their survivability during this pandemic.
\end{abstract}

Keywords: resilience; online learning; pandemic

\begin{abstract}
Abstrak: Selama satu tahun pandemi Covid-19 di Indonesia, pembelajaran daring masih dilaksanakan dengan berbagai kendala. Kondisi ini membuat mahasiswa harus bertahan di tengah berbagai keterbatasan. Pada kondisi tersebut, dibutuhkan resiliensi yang baik. Penelitian ini bertujuan untuk meneliti bagaimana fase resiliensi mahasiswa miskin selama pembelajaran daring di masa pandemi Covid-19. Metode penelitian menggunakan penelitian kualitatif inkuiri naratif. Subjek penelitian dipilih menggunakan purposive sampling dengan mewawancarai 30 mahasiswa Universitas Mulawarman melalui telepon. Analisis dilakukan menggunakan proses induksi dan deduksi khas inkuiri naratif, dengan tetap berpatokan pada data lapangan namun juga mengacu pada teori sebagai bagian dari proses deduksi. Hasil penelitian menunjukkan bahwa mahasiswa melalui tiga fase dalam menghadapi pembelajaran daring, yaitu survival, adaptation, dan recovery. Masa survival dilalui ketika satu bulan pertama pembelajaran daring. Fase adaptation dilalui ketika telah melalui enam bulan pertama. Di bulan kesepuluh, mahasiswa mencapai fase recovery. Temuan ini menghasilkan rekomendasi bahwa perlu ada upaya layanan bimbingan dan konseling di perguruan tinggi untuk memfasilitasi mahasiswa miskin mengembangkan kemampuan bertahan dalam menghadapi pembelajaran daring di masa pandemi.
\end{abstract}

Kata kunci: resiliensi; pembelajaran daring; pandemi 


\section{INTRODUCTION}

The incessant Covid-19 pandemic carries significant effects on society's psychological state. A survey of 1304 respondents in China identifies that more than half of the respondents experience moderate to severe psychological consequences. Seventeen percent of the respondents report frail to moderate depression symptoms, while 30\% report moderate to severe depression symptoms (Cullen et al., 2020). In Germany, a study reveals no connection between the Covid-19 survivors' individual experiences and Covid-19 anxiety. It signifies that social and psychological determinants have more significant effects on the anxiety experienced during the initial pandemic than the direct experience of getting infected by the virus (Petzold et al., 2020).

In Indonesia, the government has instructed that all learning processes should be conducted online during the Covid-19 pandemic, causing students to be disinterested in learning (Irawan et al., 2020). Besides, some of them also witness their parents losing their jobs and become unemployed. Consequently, students are unable to afford an internet connection, proper nutrition, learning devices, stable Internet connection, and sufficient learning period since they have to work and help their parents. The problems become more complicated for students coming from minorities groups, such as the poor, village, and disable groups, who have had initial issues on attaining qualified education (Lubkov et al., 2020). The learning complication during the pandemic forces the students to have the resilience to survive since it highly affects the quality of their learning process (Ebersöhn, 2014). Essentially, resilience can be defined as the tenacity referring to positive adaptation and the ability to maintain or regain a tremendous mental state after a hardship (Herrman et al., 2011).

This study focuses on resilience's definition, not only as a characteristic that can be directly measured but also as a complicated theoretical construction to be understood. Therefore, a significant number of studies are required to comprehend an individual's resilience. Every individual has distinctive means to respond and react toward the stress triggers in their environment. For example, risk exposure can cause psychopathology and stress for some individuals, while some others present relative resistance toward the same risk level or even are capable of overcoming the anxiety and issues (Rutter, 2006).

Studies on students' resilience during the pandemic have been massively carried out. One of the studies identifies that depression and psychological well-being are not located in the same continuum (Sood \& Sharma, 2020). Another study reveals that students become psychologically unwell due to the Covid-19 pandemic, while some other students concede that learning from home provides more time for them to be together with their family, improves their psychological state (Schlesselman et al., 2020).

In addition, a study highlights two essential aspects for the college students' mental health assurance during the pandemic, namely the strategy to ensure access to mental health facilities and the broad scope of students with specific needs (Liu et al., 2020). Meanwhile, other research suggests that students present excellent time management, social interaction, mental and physical well-being, and the ability to adapt during online learning (Brammer, 2020). Besides, the counseling service is required to enhance students' autonomy in overcoming their problems (Noviza, 2015). Another study also suggests that society should develop resilience and adaptive effort to encounter the Covid-19 pandemic (Zhai \& Du, 2020).

The concerns on online learning and the limited access for poor college students place the identification of poor students' resilience phases as the essential aspects. This study seeks to identify the poor college students' resilience during the Covid-19 pandemic and find the contextual narrative to understand the research subjects' story and background.

\section{METHOD}

This study investigated students' complex experiences in completing their assignments and attending online classes during the Covid-19 pandemic. It focused on the poor college students' resilience phases, primarily in facing their learning process and assignments. The qualitative method with a narrative approach (Assjari, 2010) was adopted to looked through the research participants' stories and experiences. The approach was selected to broaden the understanding of complex human experience, in which each individual drew meaning in the social, cultural, and historical context (Rizkalla et al., 2020). 
This study used a narrative inquiry approach in the data collection process and paradigmatic narrative analysis for the data analysis, considering the Covid-19 pandemic psychological context (Sharp et al., 2019).

The paradigmatic analysis was used with inductive and deductive analysis. The inductive analysis was used for the category and theme obtained from the interview data through the constant comparative process. Meanwhile, the deductive process represents the analysis focussed on data exploration to find the existing theoretical concept or knowledge relevant to the research purposes (Sharp et al., 2019). Meanwhile, the research participants were selected purposively, with criteria are: (1) the fourths semester students in Universitas Mulawarman, (2) attended online learning through Zoom, (3) came from outside Samarinda, and (4) had low financial status, with below Rp. 2,500,000 parents income. Besides, the 30 subjects consisted of 15 male and 15 female students. The equal gender distribution aimed to be used to investigate the role of gender differences qualitatively, to confirm the results of a study that has identified no different resilience among the male and female students (Latif \& Amirullah, 2020). The subjects were interviewed three times (45 minutes each) to ensure data consistency.

\section{RESULTS}

The obtained data were analyzed using a narrative approach. The recurrent themes have been observed in each research participant individually. The initial meeting conducted by the researchers formulated the primary and sub-theme that appears in every narrative. Then, the data were coded to simplify the categorization process.

The induction process was completed to analyze the themes through the interviews with the participants. Then, the emerged theme relevant to the selected theories was used in the deduction process by investigating the concepts connected to the resilience phase (Patterson, Goens, \& Reed, 2009). From those processes, students are observed to experience three main themes, namely the survival, adaptation, and recovery stages.

\section{Survival Phase}

This phase occurs during the initial period of the pandemic. During this stage, the participants encounter psychological pressure induced by a number of problems, ranging from the high number of assignments, the parents that might get fired from their job, and the threat from the virus. This first stage is identified by the presence of stress, anxiety, unstable emotion, excessive worries, low self-esteem, low curiosity, and lack of empathy. The thirty participants explained that they encounter those symptoms when they attend online learning in the initial pandemic.

In addition, the research participants also describe their family situation during the beginning of the pandemic. Their parents' income decreases due to the social distancing policy, while the students need to purchase a high internet connection to attend the online classes. The research participants also mention their inability to buy internet connection due to the insufficient fund, so that some of them cannot participate in some classes. Consequently, they get stressed and anxious, as one of the research participants explain:

\footnotetext{
"At the beginning of the pandemic, we faced various constraints since the lecturers did not tolerate our situation. We encountered great pressure since we were going to have an examination. On the other hand, we were unable to purchase an internet connection. Even worse, the internet connection in my area is unstable. In the end, I got frustrated and anxious. I was afraid that I attained a bad grade. Thus, I asked for assistance from my lecturer."
}

The participants with unstable emotions have also experienced the survival phase. They frequently address their anger to their closest people, such as their parents and siblings. They describe that their anger release occurs due to they get irritated by their lecturers and ill-considered implementation of the educational system. Generally, when they get angry, they do activities outside their home. However, due to the social distancing policy, they have to release their stress and anger in their house. Consequently, the intensity of conflicts and disputes within their home increases significantly. The verbal conflicts mostly happen between the research participants and their siblings, while some have conflicts with their parents and spouses. 
In addition, the research participants also report that they have lower self-confidence if they fail to attend the online class. Some of their friends even bully them by making fun of their unstable internet connection, equalizing their place to the jungle. The research participants affirm that the jokes make them feel underestimated. Besides, during the online classes, when the lecturers ask them to turn on the camera, they feel uncomfortable showing their house condition.

All of the aforementioned situations lower the participants' curiosity during the initial phase of the pandemic. They have become ignorant of their surrounding. They do not have the enthusiasm to attend the online class and to finish the assignments. With the more competitive competition in their class, they feel like their friends have shown less empathy. They stop caring for their friends since they have to deal with their own issues.

\section{Adaptation Phase}

This adaptation phase is observed in the first six months of the pandemic. During this phase, the students have been habituated with pandemic-related issues, including the new learning system that requires them to complete their obligations peacefully. However, the participants still feel anxious and worry. The appearance of this second phase is indicated by the new routine consistency, acceptance of the situation, and controllable emotion. All of the 30 participants experience that indication. This phase is estimated to arise in September 2020 when the students were in their semester break after they finished the final test. One of the participants mention that during this phase, they used it to take a rest after the super exhausting online learning. Some of them also do a reflection on their online learning. They had three months of semester break and obtained all of their grades so that doing reflection is considered the proper thing to do, as one of the research participants describe:

"Actually, the online classes are not as complicated as I have expected. I still managed to get B, which

I consider relatively good. Even during the pandemic, I am no longer frightened of online learning. I

was afraid of failing to pass the class, but I actually passed the class."

In this stage, the research participant has started to get used to the new routines. In the new semester, they have been accustomed to sitting in front of their computers for hours and spending huge internet quota. The internet subsidy from the universities aids them to attend online learning. Besides, they also attain subsidies from the government, which has helped their family, so they no longer need to get a job. After they experienced unstable emotions in the previous stage, their feelings are more steady. They experience lower family conflict. When they get angry, they prefer to use the internet connection and play online games or watch YouTube videos, even if they have limited games and YouTube quota.

They confirm that they have accepted the pandemic situation. Even if they are tired of wearing masks, staying at home, and keeping their distance, they have started to aware that they should maintain to practice the protocols in order to change the situation, as explained by one of the participants:

"The situation would never change if we remain anxious but did not practice the health protocols."

\section{Recovery Phase}

In this phase, the research participants have resuscitated. They have made peace with the situation, as one of the participants described:

"We do not need to fear this situation, we only need to be cautious."

Different from the previous stage, in this stage, the participant think that they need to revive. Since they have attended online learning for two semesters, they believe that they have to start doing positive activities. This phase is estimated to occur from January 2021, during the odd semester break. The participants reveal that they are satisfied with their grades in the previous semester. Besides, they also start to get tired of the pandemic situation that has not been improved. This phase is indicated by their ability to manage their time to finish their assignments and daily activities, growing curiosity, increasing empathy, higher hopes, and ability to do positive activities or hobbies. It becomes their recovery stage from trauma and depression by being optimistic in completing their college assignments. Further, some of the research participants prefer online learning since it facilitates them to spend more time with their families. Besides, face-to-face learning demands them to spend more funds for life necessities since they have to live far away from their parents. 
Several participants admit that they meet their friends through Zoom meetings. They tell their stories and hardships to each other through that online meeting. It signifies that they have grown their sympathy. It may occur due to they have no longer perceived learning as a problem, as explained by one of the participants:

"My parents lost their jobs due to the pandemic, but they now have developed their own business. Now, we live from that business. Thus, we should not give up and keep mourning the situation. Moreover, we have been stuck in this situation for more than a year."

The research participants have developed their hopes and carry out positive activities to realize those hopes. One of the participants has started to work while continuing their studies. He opens a modest coffee shop with his friends. He explained that he only gets that opportunity to start his own business during this online learning while still following the online classes persistently. He also explains his future goals for his business enthusiastically.

The research findings suggest that most of the participants' recovery phase involves actively practice their hobbies. Almost all of the participants report that they have discovered new hobbies, such as gardening. These hobbies keep them entertained and help them reduce their boredom from heavy online learning. Additionally, their selection of hobbies is based on their social, psychological, and geographical situation. The summary of all of those research findings is illustrated in Figure 1.

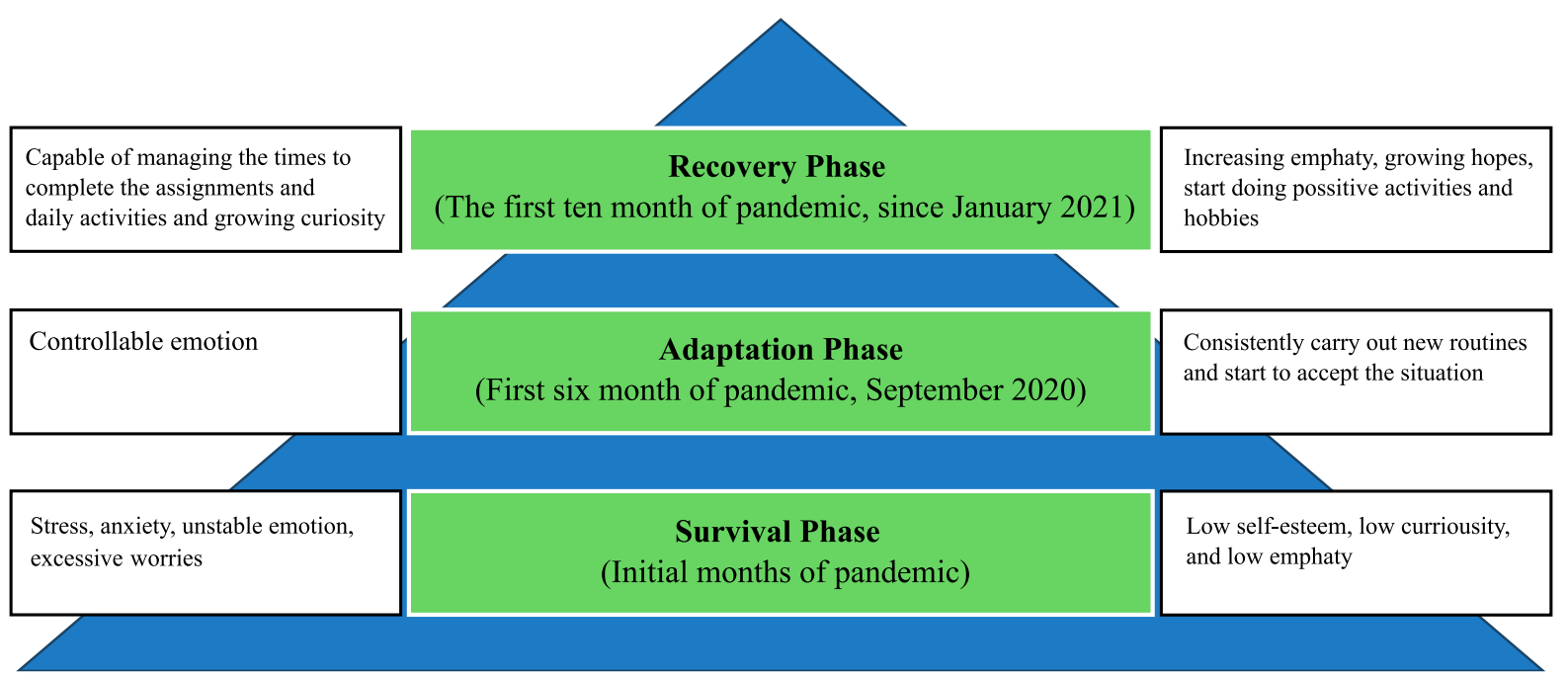

Figure 1. Summary of Participants' Resilience Phases

\section{DISCUSSION}

This study's deduction and induction phases were adopted from the resilience phases from Patterson, Goens, \& Reed (2009). The cycle begins from the expected condition, where the people have not experienced any suffering. Then, they experience misfortune in the dysfunctional phase, in which they tend to frequently get angry, become more aggressive, blame other people, and humiliate themselves. Besides, they also experience denial and grief. This phase is categorized as a dangerous phase. The next phase is adaptation, in which the individuals start to complete their obligation and get away from the dysfunctional stage. After they get through the adaptation phase, people come to the recovery phase that takes them to a more stable condition (Reed, 2018).

According to the findings in this study, the participants have not reached the highest phase of the growth stage. The participants believe that they have to continue their life, not develop their life. Some of the participants mention their future goals, but those goals only serve as the catharsis or diversion of their current situation. It is presumed to be induced by the implementation of social distancing policy which decreases their social interaction. Consequently, they have issues in finding the role model during this period. Therefore, the one-year pandemic situation only encourages them to stop complaining. The participants' inability to attain the growth phase signifies that they require more than one year to resolve the academic issues caused by online learning. Their highest phase is a recovery that marks the point to revive to normal living. 
Most of the participants affirm that this online learning is their first experience. Furthermore, they come from impoverished families with no proper access to qualified education. Similarly, a study on 430 students in China describes that $37.5 \%$ of participants have successfully obtained the growth phase postCovid-19 trauma while also accentuate that resilience and life values become the essential defender for mental health (Yu et al., 2021). Besides, the study also explains that the attainment of resilience highest stage can be difficult during a pandemic period.

According to Patterson, Goens, \& Reed (2009), resilience has a number of stages. First, the recovery stage, which is the first resilience stage representing the stable situation. During this stage, a solid strategy to remains in a secure position with proper function is required. However, individuals have not gained the ability to understand and transform their hardship into a life message. Most of the strong people will not get fascinated at this stage. Second, the growth phase is the stage II resilience phase. This phase can only be attained by strong individuals or groups with the ability to recover, learn from difficulties, and revive stronger during the calamity. However, comprehending each individuals' resilience can be challenging since each of them may attain a different phase in the same level of hardship.

After a one-year pandemic, all 30 research participants have not gained the growth phase since they have not discovered the significance of their suffering. Pearsall (2003) mentions that during the growth phase, the individuals should surpass their initial function, regain their psychological state and attain the mental and emotional message from the suffering. Meanwhile, the initial phase, the survival phase, has become the beginning phase experienced by all research participants. Survivability is extremely helpful during the pandemic situation since it aids people in facing the mental pressure brought by the situation. During the online learning shift, the participants should encounter a higher learning period so that they need survivability to pass through the initial pandemic period. The ability to withstand the initial period of this pandemic differentiates the strong and weak individuals. To pull through this situation, individuals have to own the ability to adapt and improvise (Garros et al., 2020). The next phase is the adaptation phase, which is indicated by the appearance of individuals' sense of responsibility. In this stage, individuals start to get aware of the need to enhance their quality. All of the participants mention that in the sixth month of the pandemic, they have been habituated by online learning and all of its constraints. During this period, they have been in the new semester. Therefore, the participants have had the ability to practice the new habits in this period (Tivyaeva, 2021).

The recovery stage is the next stage which also becomes the highest stage for the participants. The participants mentioned that they start to comprehend their situation in this stage, as they have interpreted their hardship as the lesson to improve themself. They have had the ability to manage their time, work on their assignments, grow their empathy, and carry out numerous positive activities, including their hobbies. This phase occurs in the tenth month of the Covid-19 pandemic in Indonesia, around January 2021. The new year momentum encourages people to formulate new plans. During this period, the participants were in their odd semester break, so they start doing possitive activities, such as the recovery efforts from the psychologal trauma they obtained from online learning. While many people wish for the pandemic to end in 2021, it remains and even gets worse. However, some of the participants experience different resilience phases, as they have been used to face hardship in their life, even prior to the pandemic. Thus, their resilience has to be enhanced to ensure their mental health (Mangestuti et al., 2020).

Universities have to accompany their students to overcome the constraints of online learning. They have to provide guidance and counseling services to increase the students' psychological well-being in encountering their life hardships. The services are expected to aid the students in comprehending their courses materials. This student assistance can be provided in the form of responsive services, such as the online individual or group counseling service (Naidoo \& Cartwright, 2020). The provision of this counseling should also consider the facilities, access, and culture in the universities. The counselors can provide individual counseling by giving them opportunities to the students to explain their life stories and find the solutions for their issues. To facilitate the attainment of the growth phase, the counselors can adopt various techniques, such as logotherapy (Chernin, 2020). The growth phase, the highest resilience phase, represents the situation where the individuals discover the signification of their suffering to get a meaningful life, linear to the goals of logotherapy (Chung, 1995). 
In addition to the individual service, the counselor can also implement a group counseling service. Group counseling aims to understand that the participants are not alone and can find a company during this challenging situation (Amulya, 2020). In the group setting, the participants are expected to learn to adopt the adaptive behavior, primarily the behavior related to the resilience ability.

\section{CONCLUSION}

The results of narrative inquiry analysis suggest that the research participants present conformity. They experience three stages of resilience, namely, survive, adaptation, and recovery phases. The participant encountered the survival phase during the initial stage of the Covid-19 pandemic in Indonesia. The adaptation phase is observed in the sixth month of the pandemic (September 2020), while the recovery phase happens in the semester break (January 2021). From these findings, the university is suggested to provide guidance and counseling services to enhance the students' ability to survive online learning during the pandemic, especially for students from impoverished families.

\section{REFERENCES}

Amulya, D. S. L. (2020). An experiment with online group counseling during Covid-19. In L. S. S. Manickam (Ed.), COVID-19 pandemic: Challenges and responses of psychologists from India (pp. 182-197). Centre for Applied Psychological Studies Thiruvananthapuram.

Assjari, P. S. (2010). Desain penelitian naratif. Jurnal Asesmen dan Intervensi Anak Berkebutuhan Khusus, 9(2), $172-183$.

Brammer, M. S. (2020). Student Resilience and COVID-19. SSRN Electronic Journal. https://doi.org/10.2139/ ssrn. 3637824

Chernin, J. (2020). COVID-19: Finding Opportunities for Positive Change. Goodtherapy.

Chung, M. C. (1995). Reviewing Frankl's will to meaning and its implications for psychotherapy dealing with post-traumatic stress disorder. Medicine and War, 11(1), 45-55. https://doi.org/10.1080/07488009508409196

Cullen, W., Gulati, G., \& Kelly, B. D. (2020). Immediate psychological responses and associated factors during the initial stage of the 2019 Coronavirus disease (COVID-19) epidemic among the general population in China. QJM: Monthly Journal of the Association of Physicians, 113(5), 311-312. https://doi.org/10.1093/qjmed/ hcaa110

Ebersöhn, L. (2014). Teacher resilience: Theorizing resilience and poverty. Teachers and Teaching: Theory and Practice, 20(5), 568-594. https://doi.org/10.1080/13540602.2014.937960

Garros, D., Austin, W., \& Dodek, P. (2020). How can i survive this? Coping during Coronavirus disease 2019 Pandemic. Chest, March, 1-9. https://doi.org/10.1016/j.chest.2020.11.012

Herrman, H., Stewart, D. E., Diaz-Granados, N., Berger, E. L., Jackson, B., \& Yuen, T. (2011). What is resilience? The Canadian Journal of Psychiatry, 56(5), 258-265.

Irawan, A. W., Dwisona, D., \& Lestari, M. (2020). Psychological impacts of students on online learning during the pandemic COVID-19. KONSELI: Jurnal Bimbingan dan Konseling, 7(1), 53-60. https://doi.org/10.24042/ kons.v7i1.6389

Latif, S., \& Amirullah, M. (2020). Students' academic resilience profiles based on gender and cohort. Jurnal Kajian Bimbingan dan Konseling, 5(4), 175-182. https://doi.org/10.17977/um001v5i42020p175

Liu, C. H., Pinder-Amaker, S., Hahm, H. "Chris," \& Chen, J. A. (2020). Priorities for addressing the impact of the COVID-19 pandemic on college student mental health. Journal of American College Health, https://doi.org/ $10.1080 / 07448481.2020 .1803882$

Lubkov, A. V., Gordienko, O. V., \& Sokolova, A. A. (2020). A humanitarian approach to the digitization of education. Education and Self Development, 15(3), 89-96. https://doi.org/10.26907/esd15.3.08

Mangestuti, R., Sholichatun, Y., Aziz, R., \& Wahyuni, E. N. (2020). Urgency of resilience and optimism in improving students' mental health. Jurnal Kajian Bimbingan dan Konseling, 5(4), 154-161. https://doi. org/10.17977/um001v5i42020p154

Naidoo, P., \& Cartwright, D. (2020). Where to from here? Contemplating the impact of COVID-19 on South African students and student counseling services in higher education. Journal of College Student Psychotherapy, 1-15. https://doi.org/10.1080/87568225.2020.1842279 
Noviza, N. (2015). Konseling teman sebaya (peer counseling) suatu inovasi layanan bimbingan konseling di perguruan tinggi. Wardah, 12(1), 83-98.

Patterson, J. L., Goens, G. A., \& Reed, D. E. (2009). Resilient leadership for turbulent times: a guide to thriving in the face of adversity. Lanham: Rowman \& Littlefield Education.

Pearsall, P. (2003). The Beethoven factor: The new positive psychology of hardiness, happiness, healing, and hope. . Charlottesville, VA: Hampton Roa.

Petzold, M. B., Bendau, A., Plag, J., Pyrkosch, L., Mascarell Maricic, L., Betzler, F., Rogoll, J., Große, J., \& Ströhle, A. (2020). Risk, resilience, psychological distress, and anxiety at the beginning of the COVID-19 pandemic in Germany. Brain and Behavior, 10(9), 1-10. https://doi.org/10.1002/brb3.1745

Reed, D. (2018). Resilient educational leaders in turbulent times: Applying the Leader Resilience Profile ${ }^{\circledR}$ To assess resiliency in relationship to gender and age. Periferia, 10(2), 119-134. https://doi.org/10.12957/ periferia.2018.34777

Rizkalla, N., Mallat, N. K., Arafa, R., Adi, S., Soudi, L., \& Segal, S. P. (2020). "Children are not children anymore; they are a lost generation": Adverse physical and mental health consequences on syrian refugee children. International Journal of Environmental Research and Public Health, 17(22), 1-21. https://doi.org/10.3390/ ijerph17228378

Rutter, M. (2006). Implications of resilience concepts for scientific understanding. Annals of the New York Academy of Sciences, 1094(1), 1-12. https://doi.org/10.1196/annals.1376.002

Schlesselman, L. S., Cain, J., \& Divall, M. (2020). Improving and restoring the well-being and resilience of pharmacy students during a pandemic. American Journal of Pharmaceutical Education, 84(6), 677-682. https://doi.org/10.5688/ajpe8144

Sharp, N. L., Bye, R. A., \& Cusick, A. (2019). Narrative analysis. Handbook of Research Methods in Health Social Sciences, 861-880. https://doi.org/10.1007/978-981-10-5251-4_106

Sood, S., \& Sharma, A. (2020). Resilience and psychological well-being of higher education students during COVID-19: The mediating role of perceived distress. Journal of Health Management, 22(4), 606-617. https://doi.org/10.1177/0972063420983111

Tivyaeva, I. (2021). Exploring new ways in translator and interpreter training: A student adaptation perspective. New Voices in Translation Studies, 24, 104-117.

Yu, Y., Yu, Y., \& Hu, J. (2021). COVID-19 among Chinese high school graduates: Psychological distress, growth, meaning in life and resilience. Journal of Health Psychology, 33. https://doi.org/10.1177/1359105321990819

Zhai, Y., \& Du, X. (2020). Loss and grief amidst COVID-19: A path to adaptation and resilience. Brain, Behavior, and Immunity, 87(April), 80-81. https://doi.org/10.1016/j.bbi.2020.04.053 